\title{
Magmatic and Hydrothermal Inclusions in Carbonatite of the Magnet Cove Complex, Arkansas
}

\author{
Bruce E. Nesbitt and William C. Kelly \\ Department of Geology and Mineralogy, The University of Michigan, Ann Arbor, \\ Michigan 48109, U.S.A.
}

\begin{abstract}
The carbonatite at Magnet Cove, Arkansas, USA contains a great variety and abundance of magmatic and hydrothermal inclusions that provide an informative, though fragmentary, record of the original carbonatite melt and of late hydrothermal solutions which permeated the complex in postmagmatic time. These inclusions were studied by optical and scanning electron microscopy.

Primary magmatic inclusions in monticellite indicate that the original carbonatite melt contained approximately $49.7 \mathrm{wt} \% \mathrm{CaO}, 16.7 \% \mathrm{CO}_{2}, 15.7 \%$ $\mathrm{SiO}_{2}, 11.4 \% \mathrm{H}_{2} \mathrm{O}, 4.4 \% \mathrm{FeO}+\mathrm{Fe}_{2} \mathrm{O}_{3}, 1.1 \% \mathrm{P}_{2} \mathrm{O}_{5}$ and $1.0 \% \mathrm{MgO}$. The melt was richer in $\mathrm{SiO}_{2}$ and iron oxides than the carbonatite as now exposed; this is attributed to crystal settling and relative enrichment of calcite at shallower levels. The density of the carbonatite melt as revealed by the magmatic inclusions was approximately $2.2-2.3 \mathrm{~g} / \mathrm{cc}$. Such a light melt should separate rapidly from any denser parent material and could be driven forcibly into overlying crustal rocks by buoyant forces alone. Fluid inclusions in apatite suggest that a separate (immiscible) phase composed of supercritical $\mathrm{CO}_{2}$ fluid of low density coexisted with the carbonatite magma, but the inclusion record in this mineral is inconclusive with respect to the nature of any other coexisting fluids. Maximum total pressure during $\mathrm{CO}_{2}$ entrapment was about 450 bars, suggesting depths of $1.5 \mathrm{~km}$ or less for apatite crystallization and supporting earlier proposals of a shallow, subvolcanic setting for the complex.

Numerous secondary inclusions in the Magnet Cove calcite contain an intriguing variety of daughter minerals including some 19 alkali, alkaline earth and rare earth carbonates, sulfates and chlorides few of which are known as macroscopic phases in the complex. The exotic fluids from which the daughter minerals formed are inferred to have cooled and diluted through time by progressive mixing with local groundwaters. These fluids may be responsible for certain late veins and elemental enrichments associated with the complex.
\end{abstract}




\section{Introduction}

The carbonatite in the Magnet Cove Complex of central Arkansas contains a variety of magmatic and hydrothermal inclusions visible only on a microscopic scale. These are small, but true, samples of the original carbonatite "magma" and of later hydrothermal solutions associated with the complex and, as such, provide the only direct means for study of these fluids which have been a subject of extensive speculation in the literature. The primary objectives of this preliminary investigation have been to determine the bulk composition and density of the carbonatite melt and the character of any coexisting fluid phases and to determine compositional variations of the postmagmatic hydrothermal solutions.

Relatively few carbonatites contain fluid or once-fluid inclusions of the quality seen in Magnet Cove minerals. A survey of 150 polished inclusion plates, chiefly of coarse calcite from 23 worldwide carbonatite localities, showed that in most cases the crystals either trapped extremely small inclusions or none at all or that the material was so altered or recrystallized that inclusions could not be viewed in pristine condition. Even at Magnet Cove there are some problems of this kind, particularly with apatite which contains inclusions that are relatively large and abundant but of uncertain history. Such problematic inclusions will be briefly described, but emphasis was placed upon analysis of magmatic inclusions in monticellite and of hydrothermal inclusions in calcite which offer unambiguous new information.

Special techniques had to be employed in this study. Most of the Magnet Cove inclusions are small (typically less than $50 \mu \mathrm{m}$ ) and round so that their contents are difficult to examine optically due to total internal reflection and vertical superposition of phases within the inclusions. Consequently, much of the present work involved scanning electron microscopy of opened hydrothermal or magmatic inclusions using methods recently developed by Metzger et al. (1977).

\section{General Setting}

The Magnet Cove Complex occupies about 12 square $\mathrm{km}$ in the northeastern part of Hot Spring County of central Arkansas (Fig. 1). The geology of this classical carbonatite locality has been fully described most recently by Erickson and Blade (1963) and only a few bare essentials of their summary need be repeated here.

The complex is composed of a series of post-Mississippian ring dikes that intruded folded and faulted Paleozoic shales, sandstone and novaculite of the Ouachita geosyncline. It has a core of ijolite and carbonatite, an intermediate ring of trachyte and phonolite, an outer ring of nepheline syenite, and two masses of jacupirangite located along its northern and western edges. Erickson and Blade conclude that the age sequence from oldest to youngest is phonolite and trachyte, jacupirangite, alkalic syenite, ijolite and carbonatite. The carbonatite forms at least three central bodies composed of white to light gray, coarse-grained calcite with scattered concentrations of apatite, monticellite, magnetite, perovskite, kimzeyite, biotite and pyrite.

Contact effects extend for distances up to 2500 feet into the surrounding sedimentary rocks; the sandstones and novaculites showing various degrees of recrystallization and the shales have been converted to spotted argillites, hornfels and gneiss. Alteration of ijolite xenoliths and wallrock by the carbonatite is described by Fryklund et al. (1954) as follows: (1) an outer rim of magnetite 


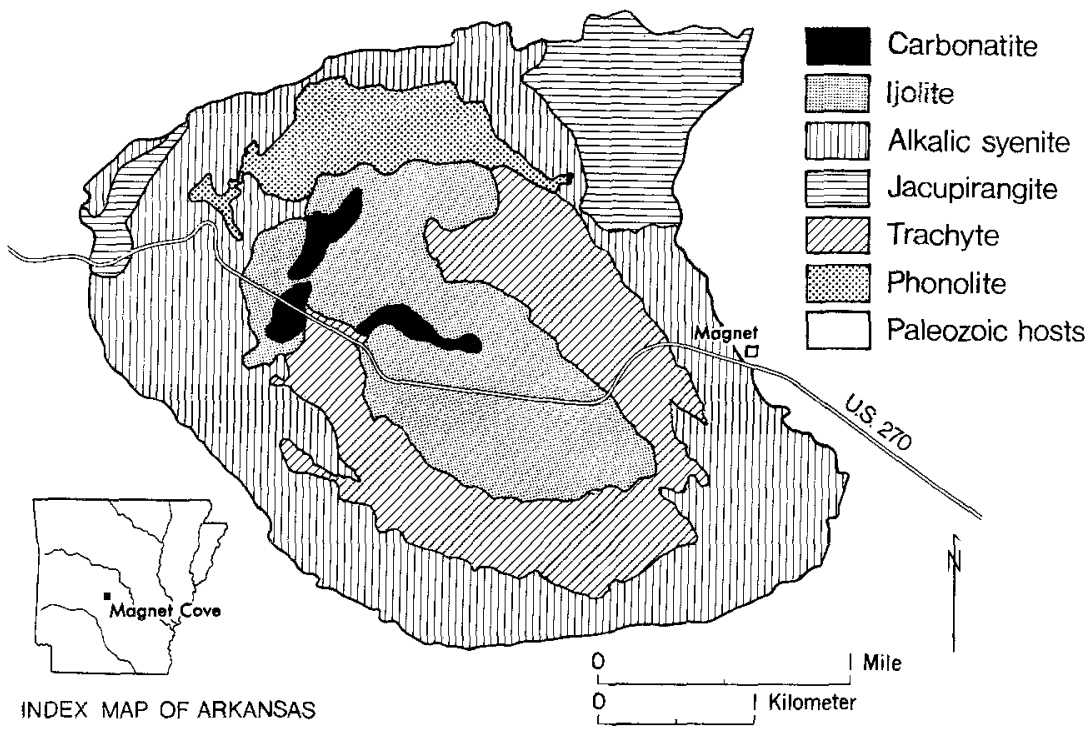

Fig. 1. General geology and index map of the Magnet Cove Complex simplified from Erickson and Blade (1963)

and pyrrhotite in medium-grained calcite; (2) a zone rich in green biotite; (3) a zone rich in vesuvianite; (4) remnant of original ijolite with some development of vesuvianite, epidote and muscovite.

No fenitization has been recognized within the immediate district, but Erickson and Blade did find an increase in $\mathrm{Sr}, \mathrm{Ba}, \mathrm{Zr}, \mathrm{La}, \mathrm{Nb}$ and $\mathrm{V}$ in country rocks of the contact zone (Etickson and Blade, 1963, p. 59). They also describe a variety of late dikes and veins which cut the complex.

\section{Techniques}

Standard techniques were at first used in the preparation and study of the inclusions in 200 polished thick $(\sim 1 \mathrm{~mm})$ plates and 6 polished thin sections prepared from 50 specimens of the carbonatite unit. However, due to the optical problems previously mentioned and, in particular, to the difficulty of identifying numerous daughter crystals present in the inclusions, emphasis was shifted to scanning electron microscopy. Only a synopsis of the methods is given here, because they are described in detail by Metzger et al. (1977).

Two different methods were used in preparing the magmatic and hydrothermal inclusions for study under the scanning electron microscope (SEM). The magmatic inclusions were exposed and polished by normal preparation of the fluid inclusion plates and polished thin sections. The hydrothermal inclusions were exposed by fracturing or cleaving the host crystal (chiefly calcite) in order to avoid plucking which occurs if the inclusions are prepared by normal cutting and polishing or the solution of daughter crystals which occurs if the inclusions are opened by decrepitation. Actually, both types of inclusions contain $\mathrm{H}_{2} \mathrm{O}$ and $\mathrm{CO}_{2}$ fluid phases that are lost in the processes; the difference in technique was to avoid otherwise certain loss of daughter crystals that are more loosely held by the water-rich inclusions. With both methods, it is impossible to open an individual inclusion pre-selected by optical study and then to study it with the SEM. However, numerous polished or opened inclusions appear in all plates prepared and, once located and analyzed with the SEM, these are re-examined optically and can be related to other inclusions still preserved beneath the plate surfaces.

Typical SEM views of the inclusions are shown in Figures 12-21. Preliminary SEM examination included observations of the number and proportions of daughter minerals present and of any 
evidence for their crystallization sequence. Where more exact proportions of phases were needed for magmatic inclusions, tracings were made of photographs taken with the SEM and the areas representing each phase in the polished inclusions were cut out and weighed on a chemical balance. Crystal morphologies were also recorded as an aid to daughter mineral identifications. The contact and overgrowth relationships of the daughter minerals and the inclusion walls were also examined closely for evidence of "cognate" matter precipitated within the inclusions (discussed below).

After such preliminary work, the electron beam, $100 \AA$ in diamter, was positioned on selected daughter crystals for semi-quantitative analysis. The characteristic $\mathrm{X}$-ray spectrum of the unknown produced by the electron beam is sensed by a solid state X-ray detector and displayed on the screen of a multichannel analyzer where it can be traced or photographed. Spectra of unknowns were routinely compared with those of known compounds run at the same voltages and counting rates in order to estimate approximate compositions. At best, the technique is an approximate one giving amounts of detectable elements to within about $\pm 10 \mathrm{wt} \%$. Where more precise analyses were needed the spectra of the unknowns and standards were compared by the use of the data reduction program Empadar VII of Rucklidge and Gasparrini (1969). In order to use this procedure corrections must be made for both background radiation and variations in take off angle. This technique was especially useful in distinguishing among larnite (?), merwinite and monticellite in the magmatic inclusions.

Limitations and sources of error in the SEM technique are discussed by Metzger et al. (1977). The errors stem from a variety of problems such as interferences from surrounding minerals, orientation of the faces of the crystal being analyzed and difficulties in comparing the spectra of unknowns and standards. The electron beam penetrates a mineral about 3 to 5 microns at an operating voltage of $25 \mathrm{kV}$ (Anderson, 1966, p. 62). The exact penetration is a function of mineral density and increases as the density decreases. Consequently, a beam can produce interference from surrounding minerals or host material especially when analyzing low density materials. This problem can be eliminated or at least minimized by lowering the accelerating voltage to about $15 \mathrm{kV}$ (lowering penetration to $1-2$ microns), or by repositioning the beam, or by both.

For present purposes, the most serious limitation of the SEM technique is its inability to detect elements lighter than sodium, thus making the distinction of hydrates from oxides or carbonates difficult. Comparison of absolute peak heights of detected elements in knowns and unknowns can solve this problem, but not in fortuitous cases where an unknown could be, for example, either a carbonate or hydrated oxide having the same weight percentages of detectable Ca.

In view of these errors, we have had to adopt some scheme to convey the relative eertainty or uncertainty of the daughter mineral identifications. Where the identification is definite, no question is indicated. Where the mineral name is written "glauberite(?)", the identification is probably correct; the mineral contains $\mathrm{Na}: \mathrm{Ca}: \mathrm{S}$ in the correct proportions $2: 1: 1$. But if the name is given as "glauberite(??)" we know only that it is some sodium-calcium sulfate and the name is only an informed guess.

\section{Related Information}

Much of the controversy over carbonatites centers upon the composition and state of the originall melt and their changes as crystallization progresses. A major breakthrough in the debate came with the experimental work of Wyllie, Tuttle and their associates (e.g., Wyllie and Tuttle, 1960a and b; Wyllie, 1965, 1966, 1967; Franz and Wyllie, 1966; Van Groos and Wyllie, 1973; Huang and Wyllie, 1974; Wyllie and Biggar, 1966; Wyllie and Haas, 1966) who, collectively, have demonstrated that melts of varied composition can precipitate calcite over a wide P-T range, persisting to temperatures down to the order of $600^{\circ} \mathrm{C}$ and that such melts could be derived either as residual fractions from crystallization of alkali peridotite magma or as immiscible alkali carbonate magmas coexisting with a parent peridotite magma. In their studies of the system $\mathrm{CaO}-$ $\mathrm{MgO}-\mathrm{SiO}_{2}-\mathrm{CO}_{2}-\mathrm{H}_{2} \mathrm{O}$, Franz and Wyllie (1967) determined two reactions of particular interest to the present investigation: 


$$
\begin{aligned}
& \text { Calcite + Monticellite + Periclase + Vapor } \\
& =\text { Forsterite }+ \text { Liquid ca. } \mathrm{T}=895^{\circ} \mathrm{C}, \mathrm{P}=1 \mathrm{~kb} \text {, } \\
& \text { Portlandite }+ \text { Monticellite }+ \text { Calcite }+ \text { Brucite }+ \text { Vapor } \\
& =\text { Liquid } \quad \mathrm{ca} . \mathrm{T}=605^{\circ} \mathrm{C}, \mathrm{P}=1 \mathrm{~kb} \text {. }
\end{aligned}
$$

Franz and Wyllie stated that the liquid phase in reaction (1) was found to be enriched in $\mathrm{CaCO}_{3}$ when compared with reaction (2) and its vapor phase contains considerably more $\mathrm{CO}_{2}$ than the vapor phase of reaction (2). In the peritectic reaction (1), forsterite becomes unstable upon cooling and reacts with a $\mathrm{CaCO}_{3}$-rich melt to form calcite, monticellite, periclase and vapor. Franz and Wyllie regard the liquid of reaction (2) as a "synthetic carbonatite magma" since it is capable of precipitating calcite at low temperatures and pressures on the order of $1 \mathrm{~kb}$. However, they acknowledge that the analogy of the liquid of reaction (2) to natural carbonatite magmas is complicated by such factors as the supersolidus crystallization of portlandite and the fact that the vapor phase involved in this reaction is almost pure $\mathrm{H}_{2} \mathrm{O}$. Implications of their work will be further discussed below.

The nature and composition of fluids responsible for fenitization have also posed a long-lasting enigma. Numerous authors like von Eckermann (1948), Swift (1952) and more recently Currie and Ferguson (1971) have inferred temperatures and compositions for fenitizing fluids from observations of changes in wallrock mineralogy and chemistry. However, this approach to studying hydrothermal fluids related to carbonatites is generally limited by the great number of variables involved such as $\mathrm{T}, \mathrm{P}$, composition of the fluid phase and composition of the country rock.

\section{Petrology of the Inclusion-Bearing Minerals}

The 50 carbonatite specimens studied consist chiefly of seven primary minerals in the following order of decreasing abundance: calcite, apatite, monticellite, Mg-rich magnetite (magnesioferrite), perovskite, phlogopite and pyrite. Informative inclusions occur only in the calcite, apatite and monticellite, and so the relative paragenesis of these minerals is most pertinent.

In general, the apatite and monticellite occur as early fragments and crystals suspended in a matrix of later calcite, but on a microscopic scale there is evidence of more overlap. Crystallization evidently began with the formation of forsterite, a mineral now preserved only where included in apatite or monticellite. The forsterite was apparently eliminated by its peritectic reaction with the melt to form monticellite (similar to reaction 1 of Franz and Wyllie, 1967). The apatite contains small solid inclusions of both forsterite and monticellite (Figs. 2, 4) indicating that it also began to form early and at least prior to the complete destruction of forsterite. Minor early calcite also occurs as isolated solid inclusions in the apatite (Fig. 4), but the bulk of the calcite is thought to have crystallized after both apatite and monticellite since it embays and is the supporting matrix for both these minerals. The extent to which early 

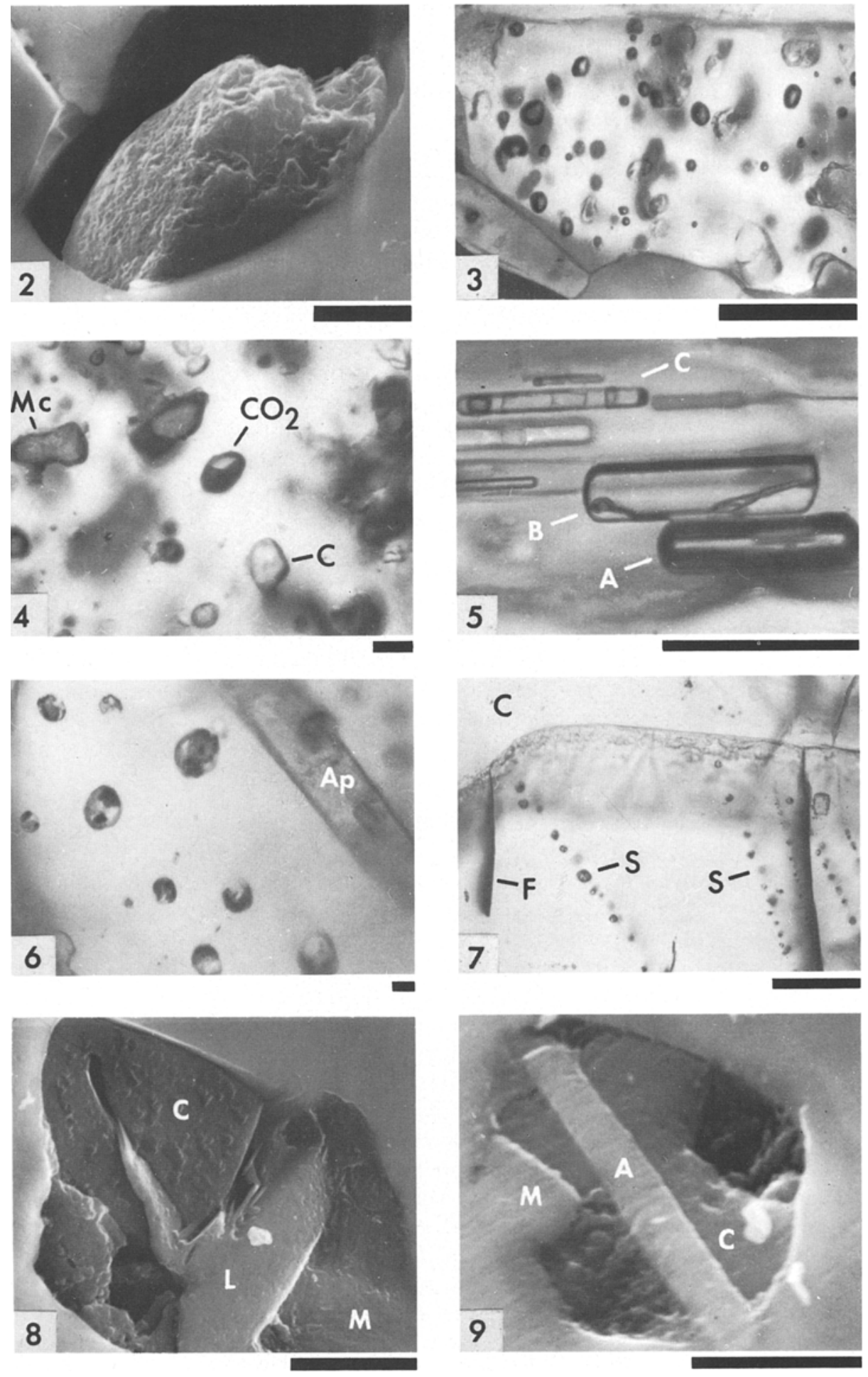
apatite and monticellite were imported from a deeper scene of crystallization, as opposed to crystallizing in situ with later calcite is not revealed by the textures.

The carbonatite has not been pervasively deformed, but there are strain features on a small scale that probably relate to movements during and shortly after magma emplacement. In some thin sections, the calcite shows microscopically local warping of cleavages and twin lamellae and associated undulose extinction. Within such areas the original calcite is partially recrystallized and replaced by a mosaic of clear, inclusion-free, tiny grains showing a high degree of grain boundary equilibration. Different generations of fracturing can also be recognized. Some fractures in early monticellite were evidently healed by magma prior to crystallization of the surrounding calcite matrix (Fig. 7). Some later fractures in calcite extend continuously across monticellite. Such relationships will be later discussed as they relate to the timing and origin of observed fluid inclusions.

Fig. 2. SEM view of solid monticellite inclusion in apatite. Open space around monticellite was originally occupied by fluid phase. Black bar scale represents $5 \mu \mathrm{m}$

Fig. 3. Typical inclusion-rich crystal of apatite in calcite. Polished thin section viewed in transmitted light. Black bar scale represents $100 \mu \mathrm{m}$

Fig. 4. Solid inclusions of monticellite $(M c)$ and calcite $(C)$ and primary inclusions of compressed $\mathrm{CO}_{2}$ gas $\left(\mathrm{CO}_{2}\right)$ in apatite. Polished thin section viewed in transmitted light. Black bar scale represents $10 \mu \mathrm{m}$

Fig. 5. Tubelike inclusions in apatite. Inclusion $A$ filled chiefly by $\mathrm{CO}_{2}$ gas plus some solids. Inclusion $B$ filled chiefly by liquid water; strongly birefringent, finely crystalline solid material (probably calcite) coats bottom of this inclusion. Inclusion $C$ contains several unidentified daughter crystals, liquid $\mathrm{H}_{2} \mathrm{O}$ and a bubble of $\mathrm{CO}_{2}$ gas. Polished thin section viewed in transmitted light. Black bar scale represents $20 \mu \mathrm{m}$

Fig. 6. Primary inclusions of crystallized carbonatite magma in monticellite. Crystal of apatite (Ap) was trapped along same growing crystal face as the magmatic inclusions. Polished thin section viewed in transmitted light. Black bar scale represents $10 \mu \mathrm{m}$

Fig. 7. Secondary magmatic inclusions $(S)$ along healed fractures in monticellite crystal. Later, crosscutting fractures $(F)$ are unhealed. Note that secondary inclusion planes do not continue into surrounding calcite $(C)$. Polished thin section viewed in transmitted light. Black bar scale represents $100 \mu \mathrm{m}$

Fig. 8. SEM view of magmatic inclusion exposed in polished surface of monticellite. The solid daughter phases include calcite $(C)$, a dicalcium silicate, probably larnite (?) $(L)$, and a crystal of magnetite $(M)$ which is covered by a thin film of calcium silicate. Void spaces formerly filled by $\mathrm{H}_{2} \mathrm{O}$ liquid and $\mathrm{CO}_{2}$ gas. Black bar scale represents $5 \mu \mathrm{m}$

Fig. 9. SEM view of a magmatic inclusion exposed in polished surface of monticellite. The solid daughter phases consist of predominant calcite and lesser amounts of magnetite and a thin crystal of apatite. Black bar scale represents $5 \mu \mathrm{m}$ 


\section{Inclusions in Apatite}

\section{Description}

The solid inclusions of forsterite, monticellite and calcite in apatite were previously described. These are accumpanied by a variety of fluid or once-fluid inclusions that are so abundant that the mineral is consistently spotted or cellular in appearance (Fig. 3). Even the tiniest of apatite crystals isolated in clear calcite or monticellite stand out clearly because of this high inclusion content. The porosity of the apatite due to the fluidfilled vacuoles range from 2 to 17 volume percent and averages about $9 \%{ }^{1}$.

The fluid inclusions vary in form from tiny, near spherical bodies typically $10 \mu \mathrm{m}$ in diameter (Figs. 3, 4) to slender tubes up to $30 \mu \mathrm{m}$ long that are aligned with the $\mathrm{C}$-axis of the host apatite crystals (Fig. 5). The spherical type is much more common than the tubes. Both types may occur within a single crystal but tend to be segregated. They do not seem to differ in contents, although the contents are more easily seen in the tubular types.

Others have observed similar tubes in apatite. Wyllie et al. (1962) suggest that such tubes are primary growth features in apatite and are indicative of a magmatic origin for the mineral. In very similar tubes in apatites of ijolites from West Kenya, Rankin and Le Bas (1974) observed immiscibility of silicate and carbonatite liquids at temperatures above $820^{\circ} \mathrm{C}$.

The contents of these inclusions in Magnet Cove apatite vary so chaotically from one inclusion to the next that it is difficult to describe them in any incisive way. Essentially three types of material are contained; (1) compressed $\mathrm{CO}_{2}$ gas, (2) liquid $\mathrm{H}_{2} \mathrm{O}$ of unknown dissolved salt content and (3) a variety of crystalline daughter minerals that vary from discrete euhedral crystals to an extremely fine-grained, strongly anisotropic "mush". These materials are all illustrated in the tubular type inclusions shown in Figure 5. The majority of inclusions in apatite are completely filled by $\mathrm{CO}_{2}$ gas, but the others contain mixtures of the liquid $\mathrm{H}_{2} \mathrm{O}$, solids and gas in any conceivable proportions. Some are completely filled by liquid water (discussed below), others by water and a small vapor bubble (commonly in Brownian motion), and still others by varied amounts of the solid and unidentified daughter products. Some of the inclusions that have size and form identical to neighbors are completely filled by the tannish, finely crystalline, strongly anisotropic aggregate which is probably calcite. In some cases, the original fluid phases appear to have "wetted" or adhered to solid inclusions of monticellite (Fig. 2), whereas most of the fluid (or once-fluid) inclusions are isolated in clear apatite.

If the apatite is crushed under glycerol, substantial amounts of gas-presumed to be $\mathrm{CO}_{2}$-are released from the dark, vapor-filled inclusions. The inclusions are so crowded together that the volume of gas coming from any single inclusion could not be measured, and hence internal $\mathrm{CO}_{2}$ pressures could not be determined by such tests. No liquid $\mathrm{CO}_{2}$ could definitely be seen to condense on the inclusion walls when the inclusions were cooled as low as $-75^{\circ} \mathrm{C}$, but the inclusions are dark and as much as $10 \mathrm{vol}$. \% liquid could form and still be difficult to see. Viewed at zero ${ }^{\circ} \mathrm{C}$ with excellent optics in a water-ice bath, still no liquid $\mathrm{CO}_{2}$ could be distinguished. The importance of this, as later discussed, is that it sets a maximum limit upon the bulk density of the $\mathrm{CO}_{2}$ phase as originally trapped. If no more than $10 \mathrm{vol} \%$ liquid $\mathrm{CO}_{2}$ is present at $0^{\circ} \mathrm{C}$, then from P-V-T relations in the system $\mathrm{CO}_{2}$ (Roedder, 1965) the weighted average of $10 \%$ liquid $(\rho=0.91 \mathrm{~g} / \mathrm{cc})$ and $90 \%$ gas $(\rho=0.10 \mathrm{~g} / \mathrm{cc})$ gives a maximum bulk density of $0.18 \mathrm{~g} / \mathrm{cc}$ for the original homogeneous $\mathrm{CO}_{2}$ phase. It might be noted that were these inclusions in apatite actually filled by liquid $\mathrm{CO}_{2}$, more copious amounts of released gas would be seen upon crushing, and very small traces of the second fluid phase would be conspicuous as a bubble formed in the center of the liquid at low temperatures. Geological implications of these observations are later discussed.

\section{Interpretation}

These inclusions in apatite show no relationship at all to fractures or healed fractures in their host or surrounding matrix. Their persistence and great abundance even in minute apatite needles which are totally isolated in clear, inclusion-

1 Porosities were estimated by planimetrie measurements of open voids as seen in enlarged photographs (taken in reflected light) of polished surfaces of 10 typical apatite crystals 
free monticellite or calcite strongly suggest that these are primary fluid inclusions. In spite of this, their significance is obscured by several factors. The seemingly random proportions of phases are probably due in large part to mixed entrapment of several immiscible fluids coexisting at the time of apatite growth, but the original proportions of phases were probably modified by post-entrapment recrystallization or "necking down" of these closely crowded inclusions.

As described by Roedder (1967), necking down can, in itself, produce anomalous final proportions of phases in a family of inclusions derived from an older set originally filled by the same homogeneous fluid. The mere crowding together of inclusions in the Magnet Cove apatite suggests that such effects are likely. Furthermore, a few of the observed inclusions are difficult to explain without such recrystallization. These are the inclusions containing liquid $\mathrm{H}_{2} \mathrm{O}$ as the only fluid phase. Excluding the unlikely possibility that water has leaked into such inclusions, the only way to account for these is to neck them off from other inclusions at some temperature below about $70^{\circ} \mathrm{C}$ (i.e., to explain the lack of a contraction-related vapor phase). If these inclusions have necked off, it is probable that others have as well.

Given this complication of necking down, probably superposed upon complex inclusions some of which trapped mixtures of fluid phases to begin with, the inclusion record in apatite is difficult to interpret with certainty. From the abundance of those inclusions completely filled by $\mathrm{CO}_{2}$ gas which greatly outnumber any other type, it does seem safe to infer that many, if not most, of these are true samples of an original, supercritical $\mathrm{CO}_{2}$ that coexisted with whatever other fluids were present at the time of apatite growth. Some of these inclusions probably inherited $\mathrm{CO}_{2}$ gas that was exsolved from trapped melt and/or aqueous brine in neighboring inclusions and then necked off. But there are altogether too many of these pure $\mathrm{CO}_{2}$-type inclusions to attribute to such an exsolution/necking mechanism. Furthermore, some apatite crystals contain only the gas-filled type of inclusion and, for them, primary gas entrapment is the only logical source for the observed $\mathrm{CO}_{2}$. It is the fact that all of these gas-filled inclusions, - not just a selected few -, failed to form liquid $\mathrm{CO}_{2}$ upon cooling that served as the basis for the previous estimate of the maximum density of the primary $\mathrm{CO}_{2}$ phase.

The significance of the other inclusion types, containing mixtures of phases, is more obscure. For example, the water now seen in these inclusions could have been originally trapped as still another immiscible, primary fluid (as permitted by solubility relations in the system $\mathrm{NaCl}-\mathrm{H}_{2} \mathrm{O}-\mathrm{CO}_{2}$ (Takenouchi and Kennedy, 1965) and recorded in inclusions of other magmatic systems (Roedder and Coombs, 1967)) or may in whole or part have been exsolved from water-rich carbonatite melt trapped and subsequently cooled in the inclusions. Interpretation of the solid materials seen in these mixed-type inclusions is also equivocal. Some of this material could have crystallized directly from trapped carbonatite melt, some from water exsolved from that melt after entrapment and some from brine originally trapped as a separate immiscible phase. It does seem likely that the fine-grained, anisotropic aggregates so common in these inclusions is calcite precipitated directly from trapped carbonatite magma, but even this is unproven. 
It is ironic that of the three minerals studied, apatite contains the greatest abundance of primary inclusions and yet, with the exception of the pure $\mathrm{CO}_{2}$ types, the interpretation of these inclusions is ambiguous. Fortunately, the inclusions to be described in monticellite and calcite gave more definitive information.

\section{Inclusions in Monticellite}

\section{Description}

Much of the monticellite examined contains inconspicuous but numerous magmatic inclusions which appear as tiny spherical bodies up to $25 \mu \mathrm{m}$ in diameter. These are not so closely crowded or mixed with varied inclusion types as to obscure their origins. Some of these are clearly primary, occurring along and in some cases defining growth planes in the monticellite crystals (Fig. 6). Others with similar contents are obviously secondary as they occur along healed fractures that extend all the way to the monticellite crystal faces (Fig. 7). These healed fractures never continue on into matrix calcite and so, while they postdate complete crystallization of the monticellite, they were evidently formed and healed prior to crystallization of the calcite.

These small, round inclusions are difficult to study optically. Over half of the available space is filled by miscellaneous daughter minerals usually including one strongly anisotropic mineral and one euhedral (cubic) opaque phase. The remaining space is filled by water and a dark vapor phase, presumably $\mathrm{CO}_{2}$-rich, in proportions that are roughly $4: 1$, respectively. The presence of the water increases optical relief of the inclusions but is most evident from the curving interfaces with the vapor phase. Where the vapor is tucked in among the solid phases it is distorted into films and angular fillings that are totally reflecting and look like additional opaque solid phases. When heated to temperatures well above critical for $\mathrm{CO}_{2}$, no change is seen in the liquid-vapor interface or fluid proportions, indicating that these fluid phases are not merely liquid $\mathrm{CO}_{2}+$ vapor $\mathrm{CO}_{2}$.

The SEM revealed a much more detailed picture of the texture and compositions of the solid phases precipitated within these inclusions. As illustrated in Figure 8, for example, euhedral calcite appears crosscut by dicalcium silicate, probably the low temperature polymorph larnite. The inclusion also contains a small crystal of magnetite that is coated by a thin film of the calcium silicate. Minor amounts of megnesium and iron were detected in the larnite and of $\mathrm{Na}$, $\mathrm{Mg}, \mathrm{S}, \mathrm{K}$ and $\mathrm{Fe}$ in the calcite. Minor amounts of $\mathrm{Mg}$ and $\mathrm{Fe}$ could be dissolved in the calcite but since there can be no appreciable solid solution of $\mathrm{Na}, \mathrm{K}$ or $\mathrm{S}$ in calcite or $\mathrm{Fe}$ and $\mathrm{Mg}$ in the larnite (Schairer and Osborn, 1950), these elements must reside in minute foreign phases or represent background from surrounding minerals.

Figure 9 shows another typical primary inclusion in monticellite containing a daughter crystal of apatite in addition to the more common calcite and magnetite. As in all of these magmatic inclusions in monticellite, this one shows a significant amount of void space formerly occupied by the $\mathrm{H}_{2} \mathrm{O}$ liquid and $\mathrm{CO}_{2}$ vapor seen optically.

With the aid of the SEM many primary inclusions of this kind have been examined in monticellite and most of the daughter solids have been identified on the bases of their morphology and ratios of detectable elements. Virtually all of these inclusions contain calcite as the predominant phase, the mineral commonly containing minor but detectable amounts of $\mathrm{Na}, \mathrm{K}, \mathrm{Mg}, \mathrm{P}, \mathrm{S}$ and, less commonly Al, $\mathrm{Fe}$ and $\mathrm{Cu}$. Next in abundance is either one of two silicates, one the dicalcium silicate (probably larnite) and the other a calcium-magnesium silicate with $\mathrm{Ca}: \mathrm{Mg}=3: 1$ (possibly merwinite). Common minor elements in these silicates are $\mathrm{Al}$ and $\mathrm{Fe}$ in the merwinite(?) and $\mathrm{Al}, \mathrm{Fe}$ and $\mathrm{Mg}$ in the larnite(?). The common but subordinate opaque phase is magnetite or, less commonly, the $\mathrm{Fe}-\mathrm{Mg}$ spinel, magnesioferrite. A very few inclusions show exposed crystals of apatite, as in Figure 9, and in one case a small crystal of diopside(??) was detected.

\section{Interpretation}

It is perhaps appropriate to cite some of the evidence for regarding these inclusions as true relicts of magma rather than just accidental entrapments of mineral debris caught up in the growing monticellite. Were these merely original mineral 
inclusions, it would be most difficult to explain their repeated entrapment as a persistent assemblage of minerals, all intergrown in similar proportions, all accompanied by similar fractions of attached fluid phases and all trapped as tiny spherical aggregates of similar size that occur both on growth planes and along fractures that postdate the monticellite deposition. As might be expected, some of the daughter solids found in the inclusions were also coprecipitated as macroscopic phases with the monticellite, but these are readily recognized as monomineralic solid inclusions of much more variable size and shape which are never localized by post-host fractures. Thus, all of the features described for these "magmatic" inclusions are perfectly consistent with entrapment of original melts, but are difficult to interpret in any other way.

With regard to timing of melt entrapment, it can only be said that the primary inclusions represent a melt in contact with the monticellite at some moment during its original growth. Since the extent to which a given monticellite crystal was transported after its crystallization is unknown, it is also unknown whether these melt samples came from deep in the complex or were entrapped at or close to their present levels of exposure. The secondary magmatic inclusions (Fig. 7) could have been entrapped at any time (and at any depth) after monticellite growth but prior to solidification of the surrounding calcite matrix.

As previously described, the occurrence of solid inclusions of apatite trapped in monticellite (Fig. 6), coupled with the fact that apatite crystals commonly overgrew the monticellite, indicates some time overlap in the crystallization of these two minerals. In this case, it is puzzling that none of the vapor-filled $\mathrm{CO}_{2}$ inclusions which characterize all apatite were ever seen in monticellite. The only reasonable explanation is that monticellite selectively trapped magma, but not the coexisting vapor phase. This is somewhat troublesome in that Roedder's (1965) work suggests very effective trapping of $\mathrm{CO}_{2}$ by olivine, but no other explanation can be offered.

A few heating experiments performed on these inclusions indicate very high temperatures of fluid entrapment. In an attempt to rehomogenize the inclusions for electron microprobe analysis, several of the inclusion plates were held at temperatures up to $800^{\circ} \mathrm{C}$ for up to one week, but showed little effect from this treatment. The only observable change was the production of a new, green, granular phase and slight corrosion of the magnetite. Further work is required to specify the actual trapping temperatures, but they must lie somewhere above $800^{\circ} \mathrm{C}$.

\section{Estimate of Magma Composition}

The primary magmatic inclusions in monticellite provide an opportunity to estimate the composition of the original melt from which this mineral crystallized. Using techniques previously described, the volumetric proportions of phases present in ten of the primary inclusions were determined from SEM photographs, and the resulting data are given in Table 1. Since the polished sections are chance planar cuts through the 3-dimensional inclusion assemblages, this introduces substantial variation in the proportions of phases that happen 
to be exposed, particularly for minor phases like magnetite and apatite which occupy less space in the total inclusion volume. In other words, the variations given in Table 1 are thought to reflect chance variations in phase exposure, not fundamental variations in bulk composition of the trapped fluid. The ten inclusions selected occur in 6 different crystals from 3 different specimens. The analyses do not take into account the unknown amount of "cognate" monticellite precipitated in optical continuity on the walls of the inclusions, but originally dissolved in the inclusion fluid. The observed daughter minerals do not appear deeply embedded or "anchored" in the surrounding monticellite, and thus the amount of cognate material is probably very small.

Assuming simple compositions and typical densities for each phase, the relative masses of each phase were next determined as indicated in Table 1. Void spaces measured in the inclusions were assumed to be originally filled by liquid $\mathrm{H}_{2} \mathrm{O}$ and $\mathrm{CO}_{2}$ in the approximate proportions $4: 1$ as visually estimated from unopened inclusions under a petrographic microscope. The dissolved salt content of the water is unknown and so the liquid was simply assumed to have a density of 1 . From its cooling behavior, the $\mathrm{CO}_{2}$ phase is known to be low density vapor; a density of $0.05 \mathrm{~g} / \mathrm{cc}$ was arbitrarily selected for these calculations, but errors in this estimate have no significant effect because most of the $\mathrm{CO}_{2}$ in the system is contained in calcite.

Finally, the relative masses determined in this way were used to calculate the relative contribution of each inclusion phase to the major oxide components of the inclusion system as a whole. These final figures, normalized to $100 \%$, are given in Table 1.

Clearly, such calculations involve several sources of possible error and require highly simplified assumptions, but nevertheless they offer one of the very few ways of reconstructing approximate compositions of the original melt and the only way of including more volatile components in the estimates. The significance

Table 1. Estimated composition of primary melt at monticellite forming stage

\begin{tabular}{|c|c|c|c|c|c|c|c|c|c|c|c|}
\hline \multirow{2}{*}{$\begin{array}{l}\text { Inclusion } \\
\text { phase }\end{array}$} & \multicolumn{2}{|l|}{ Vol.- $\%$} & \multirow[t]{2}{*}{ Density } & \multirow{2}{*}{$\begin{array}{l}\text { Relative } \\
\text { mass }\end{array}$} & \multirow{2}{*}{$\begin{array}{l}\text { Oxide } \\
\mathrm{CaO}\end{array}$} & \multirow{2}{*}{$\begin{array}{l}\text { Weigh } \\
\mathrm{MgO}\end{array}$} & \multicolumn{5}{|c|}{ tPercentages (normalized to $100 \%$ ) } \\
\hline & Range & Average & & & & & $\mathrm{SiO}_{2}$ & $\mathrm{P}_{2} \mathrm{O}_{5}$ & $\mathrm{H}_{2} \mathrm{O}$ & $\mathrm{CO}_{2}$ & $\begin{array}{l}\mathrm{FeO} \\
+\mathrm{Fe}_{2} \mathrm{O}_{3}\end{array}$ \\
\hline Calcite & $20-57$ & 32.2 & 2.7 & 86.9 & $21.10^{\mathrm{a}}$ & - & - & - & - & 16.58 & - \\
\hline Larnite & $22-36$ & 25.5 & 3.3 & 84.2 & 23.73 & - & 12.79 & - & - & - & - \\
\hline Merwinite & $0-19$ & 4.2 & 3.2 & 13.4 & 2.97 & 0.72 & 2.12 & - & - & - & - \\
\hline Magnetite & $0-10$ & 2.3 & 4.4 & 10.1 & - & - & - & - & - & - & 4.38 \\
\hline Apatite & $0-19$ & 2.0 & 3.1 & 6.2 & 1.50 & - & - & 1.13 & 0.05 & - & - \\
\hline Diopside & $0-8$ & 1.0 & 3,3 & 3.3 & 0.37 & 0.26 & 0.79 & - & - & - & - \\
\hline $\mathrm{CO}_{2}$ vapor & $5-9$ & 6.6 & 0.05 & 0.3 & - & - & - & - & - & 0.13 & - \\
\hline $\mathrm{H}_{2} \mathrm{O}$ liquid & $19-34$ & 26.2 & 1.0 & 26.2 & - & - & - & - & 11.36 & - & - \\
\hline Totals & - & 100.0 & - & - & 49.67 & 0.98 & 15.70 & 1.13 & 11.41 & 16.71 & 4.38 \\
\hline
\end{tabular}

a The weight percentages were carried to the second decimal place in order to obtain $100 \%$ totals and should not be regarded as necessarily accurate to that degree 
of the numbers in Table 1 will be treated in the Discussion section, but the primary conclusion is that the monticellite formed from a CaO-rich melt highly charged with dissolved $\mathrm{H}_{2} \mathrm{O}$ and $\mathrm{CO}_{2}$.

\section{Estimate of Magma Density}

Knowing the proportions and densities of the solids and fluids that compose these inclusions at room temperature and assuming (1) that no matter has been added to or lost from the inclusions since their initial entrapment and (2) that the reduction in total inclusion volume upon cooling and thermal contraction is negligible, it is possible to calculate the density of the original magma simply as the total mass/total volume of the inclusion at room temperature. Using the densities and averaged volume percentages of phases given in Table 2, such a calculation gives a density of $2.3 \mathrm{~g} / \mathrm{cc}$ for the monticelliteforming melt. If, instead of using the averaged phase volumes, we merely average the densities of the individual inclusions studied, the estimated melt density is $2.29 \pm 0.06 \mathrm{~g} / \mathrm{cc}$ where the error given is the standard error of the mean. Densities of the individual inclusions appear to range from 2.07 to $2.58 \mathrm{~g} / \mathrm{cc}$, but that variation reflects chance exposure of phases in the flat cuts through the inclusions examined.

Thermal expansion data are available for monticellite (Skinner, 1966). Upon cooling from $1000^{\circ} \mathrm{C}$ to room temperature an inclusion in monticellite would contract in total volume by $3.64 \%$, and this would have the effect of decreasing the melt density estimate to $2.2 \mathrm{~g} / \mathrm{cc}$. The indeterminable amount of cognate monticellite, assumed negligible in these calculations, would in fact have some influence. But even if it were assumed that as much as 10 vol. \% of the inclusion matter is cognate monticellite now located on the inclusion walls, this would have the effect of increasing the melt density estimate to $2.4 \mathrm{~g} / \mathrm{cc}$. Thermal contractioon of the monticellite is a certainty, while significant cognate monticellite is only a possibility. Thus, the best estimate of melt density is the figure $2.2 \mathrm{~g} /$ cc which allows for thermal contraction of the inclusion; cognate monticellite deposition would probably raise this back up at most to the first estimate of about $2.3 \mathrm{~g} / \mathrm{cc}$. To our knowledge, these are the first estimates of the densities of a carbonatite melt; their significance and relations to work elsewhere are treated under Discussion.

\section{Inclusions in Calcite}

\section{Description}

Most specimens of Magnet Cove calcite examined are rich in fluid inclusions (Fig. 10), giving the mineral a rather milky appearance. The individual inclusions tend to be well rounded and vary in size from about $60 \mu \mathrm{m}$ down to the limits of optical resolution. The vast majority of these inclusions occur along extensive healed fractures in the calcite, many reaching and some crossing grain boundaries, and are certainly secondary in origin. A few comparatively isolated inclusions, remote from fractures, do occur and could be primary (Fig. 11), but there is no proof 

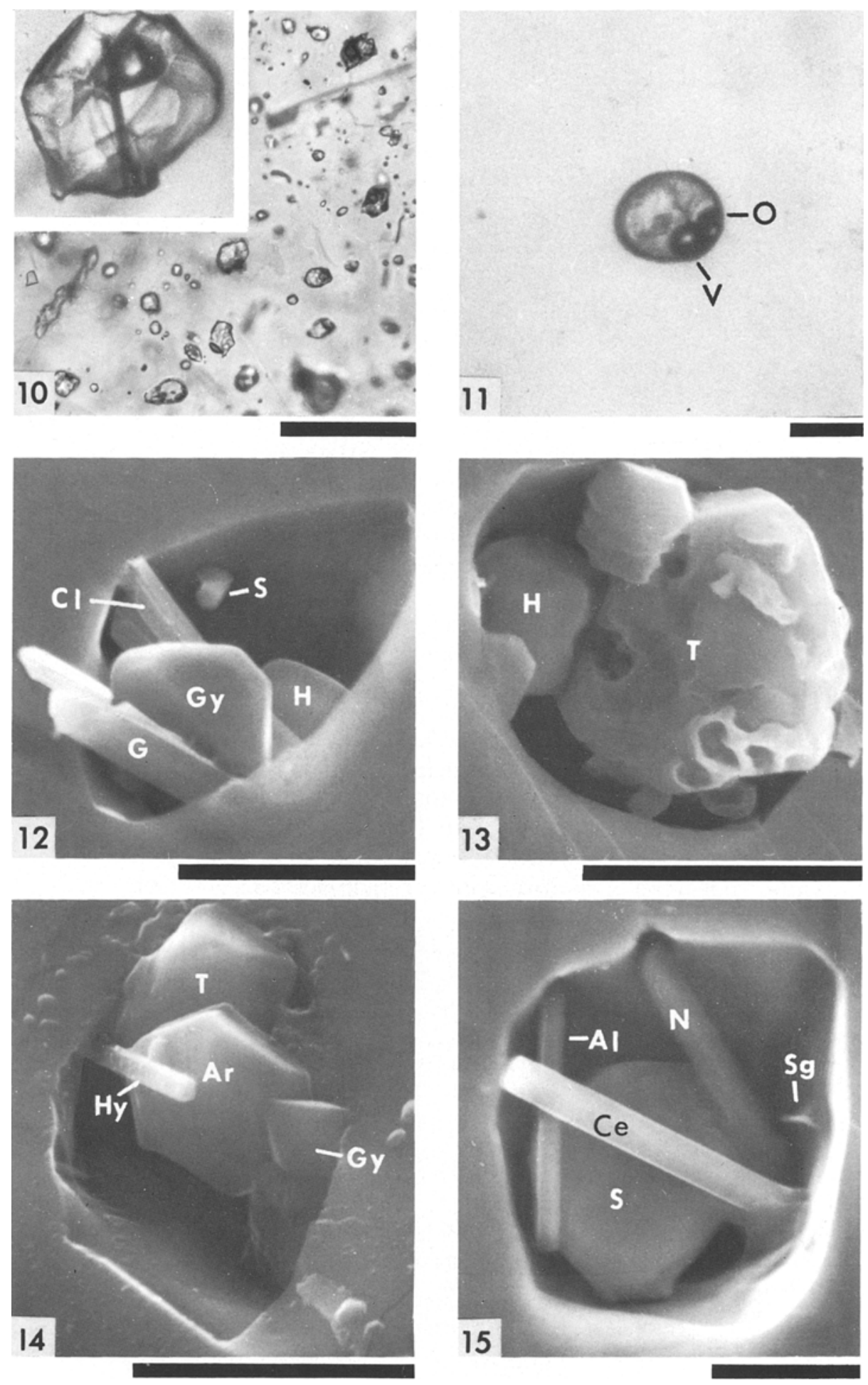
of this. Likewise, some of the numerous fracture-controlled inclusions, particularly ones of short extent in the cores of the crystals, could be pseudosecondary (i.e., formed during but before complete growth of the calcite), but there is no firm basis for sorting them out from the secondary inclusions.

Optically, the inclusions are seen to contain variable amounts of liquid $\mathrm{H}_{2} \mathrm{O}, \mathrm{CO}_{2}$-rich bubbles and a complex family of unknown daughter minerals (Figs. 10 and 11). All of the inclusions are characterized by a high proportion of water and are referred to here as "hydrothermal" to distinguish them from the magmatic inclusions previously described. Actually, the number and amounts of daughter crystals vary from zero to quantities seen in the magmatic inclusions, and so the distinction is admittedly arbitrary.

The vapor:liquid ratios are also highly varied. Typical inclusions contain a small bubble which, if not jammed in by daughter salts, moves in a thermal gradient or, if very small, displays constant Brownian motion. Some other inclusions are completely filled by the liquid $\mathrm{H}_{2} \mathrm{O}$ and these lack daughter minerals. $\mathrm{CO}_{2}$-rich inclusions of the type described in apatite are relatively uncommon, but do occur along some of the healed fractures.

Where the inclusions are well separated along a given healed fracture, they normally display constant proportions of the fluid and solid phases; those proportions typically vary from fracture-tofracture, but not along a given fracture. However, where inclusions are conjested either along a single fracture or at fracture intersections, the contents vary chaotically and were evidently modified by necking down. In inclusion-congested fields like that shown in Figure 10, it is virtually impossible to sort out inclusions belonging to one fracture or another, or to one necked group or another.

If traced through the calcite to their contacts with monticellite or apatite, most of the inclusion trains simply terminate, but not infrequently the structure will continue into the other mineral while the inclusions do not. For example, definite cracks in monticellite (of the late type seen in Fig. 7) are often perfectly aligned with planes of secondary inclusions in the calcite, but were not themselves healed by the late fluids and consequently contain no inclusions.

It is impossible to identify the numerous daughter minerals present in these inclusions by normal optical methods, but considerable success was attained using the SEM method of Metzger et al. (1977) on opened inclusions in the calcite. An intriguing variety of compounds, including unsuspected chlorides, sulfates and carbonates, was revealed and typical SEM pictures of these

Fig. 10. Typical field of crowded inclusions in calcite. Most inclusions are fracture-controlled and probably of secondary origin (see text). The inset photograph is an enlargement of one of these inclusions, $25 \mu \mathrm{m}$ in diameter, which is filled by several transparent and opaque daughter minerals along with liquid $\mathrm{H}_{2} \mathrm{O}$ and a $\mathrm{CO}_{2}$-rich bubble. Polished thin plate of calcite viewed in transmitted light. Black bar scale represents $100 \mu \mathrm{m}$

Fig. 11. An isolated, probably primary inclusion in calcite containing several unidentified daughter salts (including one opaque phase labelled $O$ ), liquid $\mathrm{H}_{2} \mathrm{O}$ and a $\mathrm{CO}_{2}$-rich bubble $(V)$. Polished thin plate of calcite viewed in transmitted light. Black bar scale represents $10 \mu \mathrm{m}$

Fig. 12. SEM view of an opened complex inclusion in calcite containing euhedral daughter crystals of sylvite (S), halite $(H)$, gypsum (?) $(G y)$, chlorocalcite (?) (Cl), and glauberite (??) (G). Black bar scale represents $10 \mu \mathrm{m}$

Fig. 13. SEM view of an opened complex inclusion in calcite containing daughter crystals of halite $(H)$ and thenardite $(D)$. Black bar scale represents $5 \mu \mathrm{m}$

Fig. 14. SEM view of an opened complex inclusion in calcite containing daughter crystals of thenardite $(T)$, arcanite $(A r)$, hydrophyllite $(H y)$ and gypsum (?) $(G y)$. Black bar scale represents $5 \mu \mathrm{m}$

Fig. 15. SEM view of an opened complex inclusion in calcite containing daughter crystals of celestite $(C e)$, sylvite $(S)$, syngenite (?) ( $S g)$, alumohydrocalcite (??) ( $A l)$ and nahcolite (??) (N). Black bar scale represents $5 \mu \mathrm{m}$ 

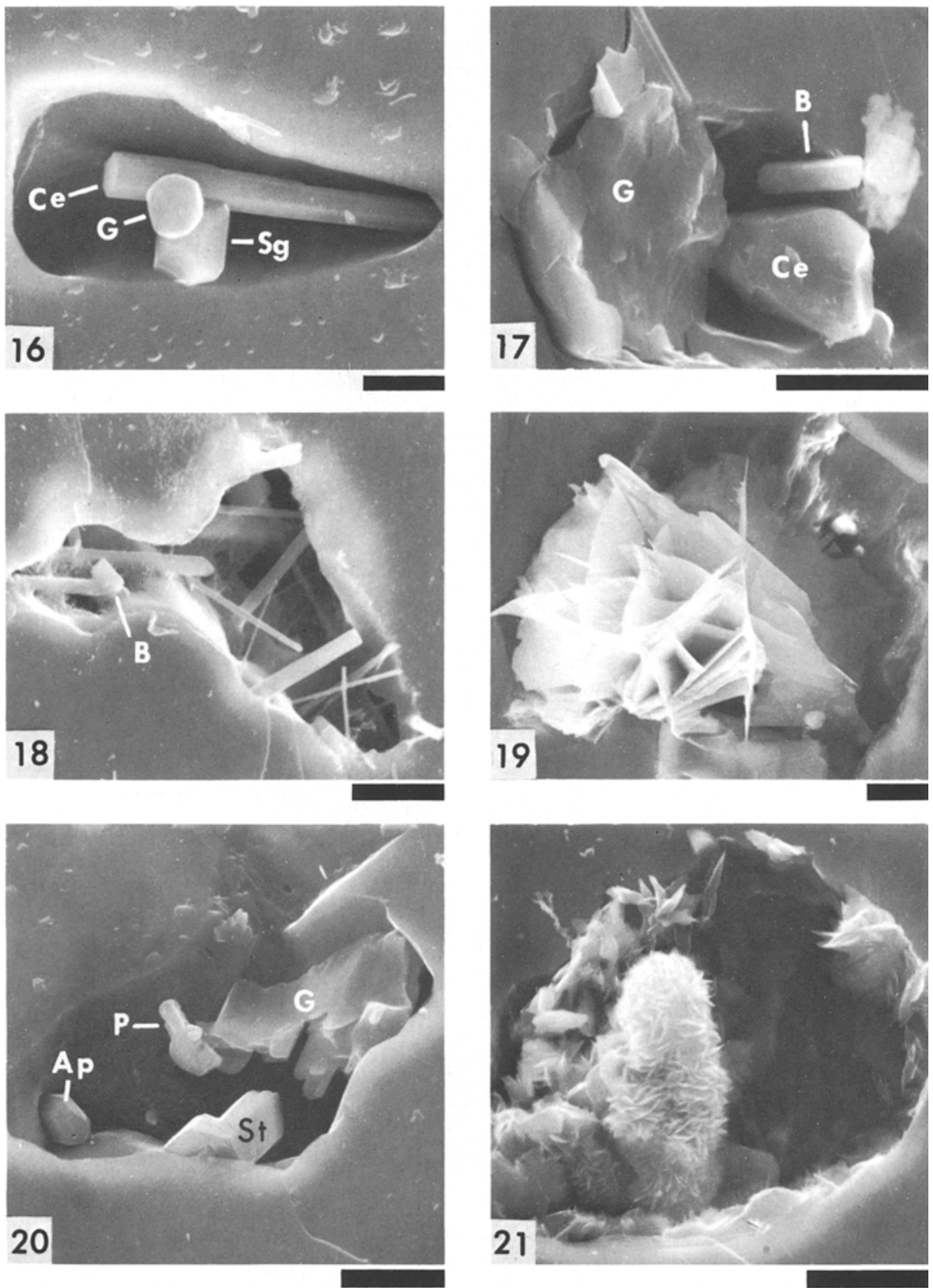

Fig. 16. SEM view of an opened intermediate inclusion in calcite containing daughter crystals of celestite $(\mathrm{Ce})$, syngenite (?) $(\mathrm{Sg})$ and glauberite (??) $(G)$. Black bar scale represents $10 \mu \mathrm{m}$

Fig. 17. SEM view of an opened intermediate inclusion in calcite containing daughter crystals of barite $(B)$, celestite $(C e)$ and glauberite $(? ?)(G)$. Black bar scale represents $10 \mu \mathrm{m}$ 
minerals are shown in Figures 12-21. A complete list of the identified or strongly suspected daughter minerals is given in Table 2. Noticeably lacking from the list of daughter minerals in the hydrothermal inclusions in calcite are those silicates and oxides that were characteristic daughter minerals in the magmatic inclusions in monticellite.

Some heating stage observations were made of these hydrothermal inclusions, but the tests were rarely successful because these inclusions tend to decrepitate at fairly low temperatures. Four

Table 2. Summary of Daughter Minerals

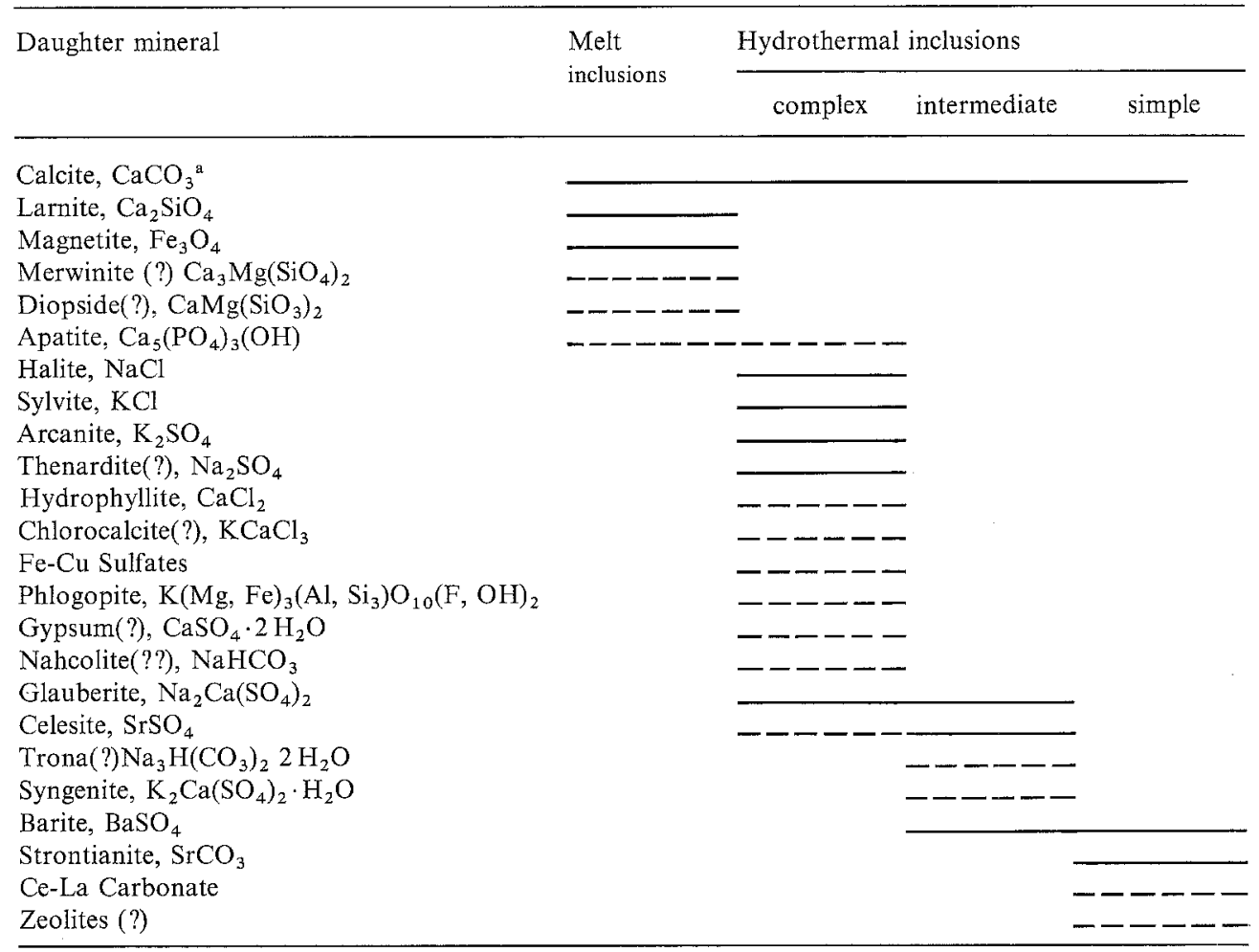

a Daughter calcite seen as discrete phase in magmatic inclusions, but only estimated as cognate material in hydrothermal inclusions in calcite

Solid lines indicate common daughter minerals and dashed lines relatively uncommon mineral

Fig. 18. SEM view of an opened simple inclusion in calcite containing numerous, needle-like daughter crystals of strontianite and a single crystal of barite $(B)$. Black bar scale represents $10 \mu \mathrm{m}$

Fig. 19. SEM view of a boxwork of cesium-lanthanum carbonate crystals occupying an opening along fracture in calcite. It is uncertain whether these are merely precipitates along a late fracture or true daughter salts in an opened fluid inclusion. See text. Black bar scale represents $10 \mu \mathrm{m}$

Fig. 20. SEM view of opened inclusion in calcite containing daughter crystals of apatite $(A p)$, a mica-probably phlogopite (?) ( $P$ ), strontianite $(S t)$ and glauberite (??) (G). Black bar scale represents $10 \mu \mathrm{m}$

Fig. 21. SEM view of opened inclusion in calcite containing daughter precipitate of a calciumaluminum silicate, probably a zeolite. Black bar scale represents $10 \mu \mathrm{m}$ 
relatively large inclusions containing the daughter mineral assemblages listed under "Complex" in Table 2 gave filling temperatures (homogenization of the fluid phases only) of 185, 200, 267, $275^{\circ} \mathrm{C}$. Six runs on "Simple" inclusions containing only $\mathrm{Sr}$ and $\mathrm{Ba}$ compounds gave filling temperatures in the range of $100-130^{\circ} \mathrm{C}$. These are clearly minimum temperature estimates, and not too meaningful at that. As usual, the positive corrections for total pressure are unknown and, furthermore, the daughter minerals were not completely re-dissolved in the runs.

Unfortunately, the relative ages of fractures containing these different daughter minerals are indeterminate. However, the daughter solids are far from random in their occurrence, and their systematic associations very probably reflect fluid variations through time. In Table 2 , the daughter compounds coexisting in the same fluid inclusions are indicated. On the basis of associations, three types of hydrothermal inclusions can be recognized: a "complex" type characterized by the greatest abundance of salts among which halite, sylvite, arcanite and thenardite are typomorphic, a "simple" type characterized by the presence of barite and strontianite, and an "intermediate" type containing salts representative of both extremes. In general, there is a decrease of daughter salt abundance from the complex to simple inclusions, although all of these inclusions are highly saline in character. There is also a perceptible difference in size, the complex types being smallest (up to $20 \mu \mathrm{m}$ ), the intermediate types ranging from 15 to $55 \mu \mathrm{m}$ and the simple types being somewhat larger and ranging up to $60 \mu \mathrm{m}$.

\section{Interpretation}

The inclusion record preserved in calcite testifies chiefly to late secondary fluids of exotic composition that penetrated this mineral at some unspecified time after its initial crystallization but possibly before complete crystallization. The fluids at this time were rich in water relative to the earlier magmatic fluids, and contained major quantities of dissolved chlorides, sulfates and carbonates. The temporal sequence of these fluids is indeterminate, but the highly systematic groupings of inclusions sizes, filling temperatures, and amounts and associations of daughter compounds strongly suggest that these fluids changed from complex to simple through time. The latest inclusions in the calcite are probably those liquid $\mathrm{H}_{2} \mathrm{O}$ filled types lacking daughter minerals which must have been trapped at some temperature below about $70^{\circ} \mathrm{C}$.

It may seem curious that most of the exotic daughter minerals detected in the hydrothermal inclusions do not occur on a macroscopic scale in the Magnet Cove alkalic complex. But as a group, most of these salts are characterized by high water solubility and are thus compounds that would be readily flushed from the system. Such behavior has familiar precedence in hydrothermal ore deposits where, in general, those compounds like halite which are most common as daughter solids in inclusions, are least common in or totally absent from the macroscopic assemblages.

It is puzzling that there is a great rarity or absence of primary magmatic inclusions in calcite. Presumably, calcite deposition overlapped the formation of apatite and monticellite in time even though the bulk of calcite is distinctly later. And yet, in the hundreds of opened inclusions in calcite examined with the SEM, no larnite, merwinite, magnetite or other daughter minerals characteristic of the magmatic inclusions in monticellite have been found. If they were trapped in the calcite, the primary fluids revealed by monticellite might form unusual inclusions in which a large proportion of the original matter $(\sim 32 \mathrm{vol} . \%)$ would crystallize as indistinguishalbe calcite on inclusion walls. 
The inclusion residue would then contain approximately $49 \%$ fluid and $51 \%$ solid phases and could thus camouflage itself as merely another hydrothermal inclusion in the calcite. However, those solid phases should still consist of the oxide and silicate daughter products found in other magmatic inclusions and there is no evidence of these from the present studies. Some of the primary (?) inclusions of the type shown in Figure 11 contain an opaque phase, probably magnetite, which has never been detected with the SEM in opened inclusions in the calcite. These could be rare magmatic inclusions in the calcite, which we have never had the luck to expose in cleaving this mineral. The alternatives are that calcite trapped no primary magma or that many of the "hydrothermal" inclusions described are indeed primary or pseudosecondary and that the melt had evolved to a drastically different composition (chloride-sulfate-carbonate rich, silicate-oxide poor) by the time late calcite was crystallizing. The latter seems most unlikely, and the authors believe that calcite simply did not trap the primary magma.

\section{Discussion}

From their comprehensive studies in the Magnet Cove area, Erickson and Blade (1963) concluded that the alkalic intrusive rocks of the complex were derived by fractional crystallization and differentiation of a residual, melanocratic phonolite magma rich in alkali, lime and volatiles. The parent for this residual fluid was inferred to be a regionally undersaturated olivine basalt magma. The carbonatite-forming fluids themselves were interpreted to be end stage, "pegmatitelike" differentiates of this process on the borderline between magmatic and hydrothermal solutions and highly charged with volatile components.

The primary magmatic inclusions described in the present study were minute samples of that original end stage melt trapped at some moment during the crystallization of monticellite. As such, they offer a special opportunity to test the earlier speculations. Approximate as they may be, the present inclusion analyses confirm that the original carbonatite magma was essentially a $\mathrm{CaO}$ $+\mathrm{CO}_{2}+\mathrm{H}_{2} \mathrm{O}$-rich melt with lesser quantities of dissolved $\mathrm{SiO}_{2}, \mathrm{P}_{2} \mathrm{O}_{5}, \mathrm{MgO}$ and iron oxides. The dissolved water and carbon dioxide contents were quite high,-about 11 and 17 w. \% respectively -, justifying the speculation that such a fluid would lie on the borderline between magmatic and hydrothermal.

Due to ambiguities introduced by selective and/or mixed trapping of fluids and of necking down of inclusions which pertain in varying degree to the different inclusion hosts, the inclusion record is unclear with respect to the number and character of fluid phases that may have coexisted with the primary carbonatite magma. The great abundance of the vapor-rich inclusions in apatite certainly suggests that at least an immiscible, supercritical $\mathrm{CO}_{2}$ fluid of low density was present within the magma. The data would also allow for, but do not give compelling evidence of, a third, $\mathrm{H}_{2} \mathrm{O}$-rich coexisting fluid. The coexistence of these two fluids with the magma would require the immiscibility of the two volatile components, $\mathrm{H}_{2} \mathrm{O}$ and $\mathrm{CO}_{2}$. The experimental work of Takenouchi and Kennedy (1965) on the miscibility of $\mathrm{H}_{2} \mathrm{O}$ brines with varying 


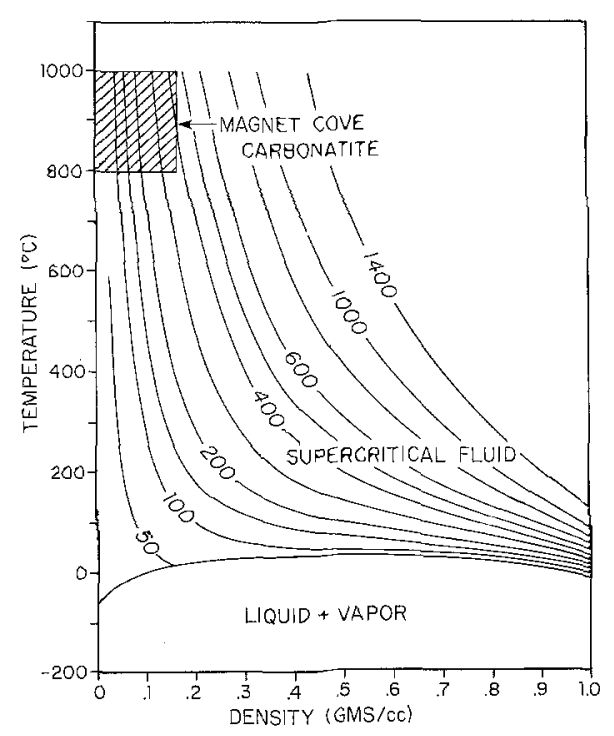

Fig. 22. P-T linits for growth of apatite in the Magnet Cove carbonatite superposed on phase relations in the system $\mathrm{CO}_{2}$. Isobars in the range $50-1400$ bars are drawn from the data of Kennedy and Holser (1966)

salinities and $\mathrm{CO}_{2}$ did not include temperatures as high as those inferred here; however, their work does show a fairly wide miscibility gap between $\mathrm{CO}_{2}$ and a solution with $20 \%$ by weight $\mathrm{NaCl}$ at $450^{\circ} \mathrm{C}$ over a pressure range of 0 to 1500 bars. In addition, the existence of two immiscible phases consisting of an $\mathrm{H}_{2} \mathrm{O}$-rich brine and a $\mathrm{CO}_{2}$-rich vapor has been reported by Roedder and Coombs (1967) in granite xenoliths within the Asension Island volcanics.

The depths and total pressures of emplacement of the Magnet Cove carbonatite are unknown. Erickson and Blade (1963) visualize a shallow, subvolcanic setting for the presently exposed units, but there is no firm stratigraphic basis for quantifying the actual depths. The $\mathrm{CO}_{2}$-filled inclusions common in apatite are helpful in this regard in that their maximum bulk density $\left(0.18 \mathrm{~g} \mathrm{CO}_{2} / \mathrm{cc}\right)$ places upper limits on total pressure at any arbitrarily chosen temperature. This is indicated in Figure 22 where the Magnet Cove conditions are superposed on P-T-V relations for the system $\mathrm{CO}_{2}$ as given by Kennedy and Holser (1966). The temperatures of carbonatite crystallization are not precisely established, but a minimum of $800^{\circ} \mathrm{C}$ is suggested by the present heating experiments and a maximum of $1000^{\circ} \mathrm{C}$ is probably a generous upper limit. The highest total pressures within this range are approximately 450 bars. This corresponds to depths of $1.5 \mathrm{~km}$ or less along a reasonable lithostatic gradient of $0.31 \mathrm{~kb} / \mathrm{km}$ (rock density $=2.8 \mathrm{~g} / \mathrm{cc}$ ). Such figures certainly support Erickson and Blade's (1963) suggestion of a shallow, subvolcanic setting, particularly since the estimates may err on the high side. They apply strictly to conditions at the moment of $\mathrm{CO}_{2}$ entrapment in apatite. We do not know the extent to which the apatite crystals moved vertically after crystallization, - either upward a times of rapid melt intrusion or downward by crystal setting at times of quiescence. Also, they are based on a maximum $\mathrm{CO}_{2}$ density which is only that! Actual $\mathrm{CO}_{2}$ densities may have been much lower. Finally, the depth estimate would include 
any topographic relief on the volcanic superstructure existing at the time of carbonatite intrusion.

If the fluids responsible for the deposition of the complex secondary and possibly primary inclusions in the calcite are representative of the volatile phase at the last stages of crystallization then this would suggest a shift in the composition of the volatile phase to much more $\mathrm{H}_{2} \mathrm{O}$-rich fluids. It is interesting that such a shift is in agreement with the work of Franz and Wyllie which was summarized earlier. In their experiments they found the volatile phase in equilibrium with their "synthetic carbonatite magma" of reaction (2) to be very rich in $\mathrm{H}_{2} \mathrm{O}$, while the vapor phase in equilibrium with the higher temperature reaction (1) contained more $\mathrm{CO}_{2}$.

It is interesting to compare the inclusion data with previously published estimates of the bulk composition of the Magnet Cove and other carbonatites. Such a comparison is given in Table 3 where the inclusion data are shown both with the actual water content (Column 1) and with that water content reduced by $90 \%$ (Column 2 ) in order to better simulate the solid, crystallized residue from such a melt. All oxide components of the inclusion composition fall within limits published for worldwide carbonatite occurrences by Pecora (1956), but he included analyses of silicocarbonatites and carbonatized silicate rocks so that the resulting component ranges are so large as to accomodate most any comparison. More meaningful are comparisons with Erickson and Blade's (1963) analyses of composite samples of the Magnet Cove carbonatite and Heinrich's (1966) compilation of analyses for numerous worldwide occurrences of bona fide carbonatites. The principal differences between the Magnet

Table 3. Composition of monticellite-forming fluid compared with bulk chemical analyses of Magnet Cove and other carbonatites

\begin{tabular}{|c|c|c|c|c|c|}
\hline \multirow[t]{2}{*}{ Oxide } & \multicolumn{2}{|c|}{ Fluid inclusions } & \multicolumn{3}{|c|}{ Bulk carbonatite analyses } \\
\hline & (1) & $(2)$ & (3) & (4) & (5) \\
\hline $\mathrm{SiO}_{2}$ & 15.7 & 17.5 & $0.1-49.6$ & 10.3 & 1.9 \\
\hline $\mathrm{CO}_{2}$ & 16.7 & 18.6 & $3.1-43.7$ & 28.5 & 39.4 \\
\hline $\mathrm{FeO}+\mathrm{Fe}_{2} \mathrm{O}_{3}$ & 4.4 & 4.9 & $0.2-18.5$ & 7.1 & 0.5 \\
\hline $\mathrm{MgO}$ & 1.0 & 1.1 & $0.1-18.8$ & 5.8 & 1.1 \\
\hline $\mathrm{CaO}$ & 49.7 & 55.4 & $4.0-55.4$ & 36.1 & 53.4 \\
\hline $\mathrm{P}_{2} \mathrm{O}_{5}$ & 1.1 & 1.2 & $0.6-6.9$ & 2.1 & 2.0 \\
\hline $\mathrm{H}_{2} \mathrm{O}$ & 11.4 & 1.2 & $0.04-2.3$ & 1.4 & 0.1 \\
\hline Others & - & - & - & 8.7 & 1.6 \\
\hline Totals & 100.0 & 99.9 & - & 100.0 & 100.0 \\
\hline
\end{tabular}

(1) Composition of original, monticellite-forming fluid including volatiltes as derived in Table 1;

$(2)=$ Composition of crystallized residue of same fluid assuming $90 \%$ loss of original $\mathrm{H}_{2} \mathrm{O}$;

(3) = Compositional ranges of oxides in carbonatites according to Pecora (1956); (4)=Average composition of carbonatites as compiled by Heinrich (1966) and including analyses of Gold (1963); (5) Composition of composite sample of the Magnet Cove carbonatite from Erickson and Blade (1963) 
Cove and world averages (higher $\mathrm{CaO}$ and $\mathrm{CO}_{2}$ and lower $\mathrm{SiO}_{2}, \mathrm{MgO}$ and iron oxide contents at Magnet Cove) express the fact that the Magnet Cove carbonatite is richer in calcite and leaner in the heavier oxides and silicates than average carbonatite. The inclusion estimates for Magnet Cove come closer to world average compositions and are considerably richer in $\mathrm{SiO}_{2}$ and iron oxide than the bulk composition of the carbonatite in which they occur. This difference is thought to indicate a high degree of differentiation due to crystal settling at Magnet Cove relative to other world localities. The fluid inclusions do not register the same degree of differentiation simply because the denser minerals precipitated in these tiny closed vessels have no place to settle.

The primary magmatic inclusions also provide one of the very few, if not the only, direct means of determining the density of the original carbonatiteforming melt, and the resulting estimates, on the order of $2.2-2.3$, have significant implications. If these figures are correct, then clearly any of the minerals known in the complex could have settled at varying rates through the parent melt during periods of liquid rest. It is just such settling that probably caused the relative enrichment of calcite in the shallow levels of the complex. Carrying this one step further, it is probable that one would encounter greater concentrations of magnetite and the heavier $\mathrm{Fe}-\mathrm{Ca}-\mathrm{Mg}$ silicates were the complex explored at depth. These low density estimates are compatible with the experiments of Wyllie and Biggar (1966) in the system $\mathrm{CaO}-\mathrm{CaF}_{2}-\mathrm{P}_{2} \mathrm{O}_{5}-\mathrm{CO}_{2}-$ $\mathrm{H}_{2} \mathrm{O}$ which showed that the synthetic carbonatite melts are highly fluid and produced very rapid settling of apatite, and even of calcite, crystals in the course of short runs. This led them, too, to suggest rapid crystal setting and differentiation during quiet periods between intrusive pulses.

The very low density of a carbonatite melt must also influence its behavior during emplacement. Whether initially spawned as an immiscible melt or derived as a residum from crystallization of alkalic peridotite magma, the light carbonatite melt should separate rapidly from the parent material and move into and upward through lighter crustal rocks. The inferred rapid, at times explosive, emplacement of carbonatite magmas is generally associated with the violent escape of dissolved volatiles, but the mere buoyant forces acting on such light and fluid melts would certainly contribute to similar effects.

The amazing variety of fracture-controlled inclusions preserved in Magnet Cove calcite testifies to a diversity of hydrothermal solutions which must have permeated the carbonatite at various times in its late magmatic and postmagmatic history. The relative chronology of these inclusions is uncertain, but the systematics of their sizes, filling temperatures and daughter mineral associations are best explained as due to progressive changes in these fluids through time. The earliest solutions were probably those now represented by the "complex" inclusions trapped at high temperature and characterized by multiphase daughter assemblages of alkali and alkaline earth chlorides, sulfates and carbonates. Through time, these solutions were probably cooled and diluted, evolving into fluids now represented by the "simple" type inclusions of lower filling temperatures and containing barite and strontianite as the predominant daughter compounds. The latest inclusions to form were probably those now completely filled by liquid $\mathrm{H}_{2} \mathrm{O}$ and which lack any daughter solids; these must have 
formed below about $70^{\circ} \mathrm{C}$ or else they would now contain a contraction vapor phase.

The ultimate sources of water and other components of these late hydrothermal fluids must be left to conjecture. It seems reasonable that many of these components, particularly of the early "complex" inclusions, were exsolved from still crystallizing magma at deeper levels in the complex and that the cooling, dilution and compositional changes toward the "simple" type inclusions reflect late stage influx of meteoric and/or connate waters to the cooling igneous system, but the inclusion evidence is non-committal in such regards. If, as suspected, the complex type inclusions represent hydrothermal solutions exsolved from or co-existing with carbonatite melt at deeper levels, then this fluid is compositionally much more complex than the simple $\mathrm{H}_{2} \mathrm{O} / \mathrm{CO}_{2}$ volatile phase normally visualized in the literature on the crystallization of carbonatite melts.

It is tempting to correlate the observed hydrothermal inclusions with processes of wallrock alteration at Magnet Cove, but the ties are vague at best. It could well be that some of these fluids, particularly those rich in barite and strontianite, are directly connected with the contact zone enrichments of $\mathrm{Sr}, \mathrm{Ba}, \mathrm{Zr}, \mathrm{La}, \mathrm{Nb}$ and vanadium reported by Blade and Erickson (1963). Also, one is compelled to wonder whether the complex type fluids have any connection with processes of fenitization. In general, the timing seems wrong, because fenitization usually precedes emplacement of carbonatite (Heinrich, 1966, p. 75) whereas the observed inclusions were trapped during or after crystallization of their calcite host. Furthermore, no fenitization has been recorded at Magnet Cove though it is well developed at Potash Sulfur Springs, $9 \mathrm{~km}$ west of the main complex (Howard, 1974). The present work does not settle such speculations, but does suggest a great potential for similar inclusion studies if extended to other intrusive facies of the complex and if applied in other districts where fenitization is well represented.

Acknowledgments. Thanks are due to F.W. Metzger and E.J. Essene for their valuable advice and discussions during the course of this research. E. Wm. Heinrich supplied many of the specimens used in the study. Detailed and constructive comments by C.G. Cunningham and R.L. Erickson were very helpful in revision of the original manuscript. Mr. Derwin Bell prepared the line drawings. We also wish to thank W.C. Bigelow and his staff at the Electron Microscopy Laboratory of The University of Michigan for their generous assistance throughout the investigation. Fluid inclusion research at the University is financially supported by the National Science Foundation.

\section{References}

Anderson, C.A.: Electron probe analysis of thin layers and small particles with emphasis on light element determinations in the electron microprobe (T.D. McKinley et al., ed.). New York: John Wiley and Sons 1966

Currie, K.L., Ferguson, John: A study of fenitization around the alkalic carbonatite complex at Callander Bay, Ontario, Canada. Can. J. Earth Sci. 8, 498-517 (1971)

Eckermann, H. von: The alkaline district of Alnö Island. Sveriges Geol. Undersok Ser. Ca. 36 (1948)

Erickson, R.L., Blade, L.V.: Geochemistry and petrology of the alkalic igneous complex at Magnet Cove, Arkansas. U.S.Geol. Soc. Profess. Papers 425, p. 94 (1963)

Franz, G.W., Wyllie, P.G.: Experimental studies in the system $\mathrm{CaO}-\mathrm{MgO}-\mathrm{SiO}_{2}-\mathrm{CO}_{2}-\mathrm{H}_{2} \mathrm{O}$ 
in Ultramafic and related rocks (P.J. Wyllie, ed), pp. 323-326. New York: John Wiley and Sons, 1967

Franz, G.W., Wyllie, P.J.: Melting relationships in the system $\mathrm{CaO}-\mathrm{MgO}-\mathrm{SiO}_{2}-\mathrm{H}_{2} \mathrm{O}$ at $1 \mathrm{~kb}$ pressure. Geochim. Cosmochimi. Acta 30, 9-22 (1966)

Fryklund, V.C., Harner, R.S., Kaiser, E.P.: Niobium (columbium) and titanium at Magnet Cove and Potash Sulphur Springs, Arkansas. U.S. Geol. Soc. Surv. Bull. 1015-B, 23-56 (1954)

Gold, D.P. : Average chemical composition of carbonatites. Econ. Geol. 58, 988-991 (1963)

Henrich, E. Wm.: The geology of carbonatites, p. 555. Chicago: Rand McNally and Co. 1966

Howard, J.M.: Transition element geochemistry and petrography of the Potash Sulfur Springs intrusive complex, Garland County, Arkansas. Unpublished M.S. Thesis, Univ. of Arkansas, 118 (1974)

Huang, W.L., Wyllie, P.J.: Eutectic between wollasonite II and calcite contrasted with thermal barrier in $\mathrm{MgO}-\mathrm{SiO}_{2}-\mathrm{CO}_{2}$ at 30 kilobars, with applications to kimberlite-carbonatite petrogenesis. Earth Planet. Sci. Lett. 24, 305-310 (1974)

Kennedy, G.C., Holser, W.T. : Pressure-volume-temperature and phase relations of water and carbon dioxide. In: Handbook of physical constants (S.P. Clark, Jr., ed.). Geol. Soc. Am. Memoir 97, 371-384 (1966)

Metzger, F.W., Kelly, W.C., Nesbitt, B.E., Essene, E.J. : Scanning electron microscopy of daughter minerals in fluid inclusions. Econ. Geol. 72, pp. 141-152 (1977)

Pecora, W.T.: Carbonatites: A review. Geol. Soc. Am. Bull. 67, 1537-1556 (1956)

Rankin, A.H., Le Bas, M.J.: Liquid immiscibility between silicate and carbonate melts in naturally occurring ijolite magma. Nature 250, 206-209 (1974)

Roedder, E.W.: Liquid $\mathrm{CO}_{2}$ in inclusions in olivine-bearing nodules and phenocrysts from basalts. Am. Mineralogist. 50, 1746-1782 (1965)

Roedder, E.W.: Fluid inclusions as samples of ore fluids. In: Geochemistry of hydrothermal ore deposits (H.L. Barnes, ed.), pp. 515-574. New York: Holt, Rinehart, and Wilson 1967

Roedder, E.W., Coombs, D.S.: Immiscibility in granitic melts indicated by fluid inclusions in ejected granitic blocks from Ascension Island. J. Petrol. 8, 417-451 (1967)

Rucklidge, J.C., Gasparrini, E.: Specifications of a computer program for processing electron microprobe analytical data: EMPADAR VII: Dept. of Geology, Univ. of Toronto, 1969

Schairer, J.F., Osborn, E.F.: The system $\mathrm{CaO}-\mathrm{MgO}-\mathrm{FeO}-\mathrm{SiO}_{2}$ : 1, Preliminary data on the join $\mathrm{CaSiO}_{3}-\mathrm{MgO}-\mathrm{FeO}$. J. Am. Ceram. Soc. 33, 160-167 (1950)

Skinner, B.J.: Thermal expansion. In: Handbook of physical constants (S.P. Clark, Jr., ed.). Geol. Soc. Am. Memoir 97, 75-96 (1966)

Swift, W.H.: The geology of Chishanya, Bihera District, Southern Rhodesia. Trans. Geol. Soc. Edinburgh 15, 346-359 (1952)

Taenouchi, S., Kennedy, G.C.: The solubility of carbon dioxide in NaCl solutions at high temperatures and pressures. Am. J. Sci. 263, $445-454$ (1965)

Van Groos, A.F.K., Wyllie, P.J.: Liquid immiscibility in the join $\mathrm{NaAlSi}_{3} \mathrm{O}_{8}-\mathrm{CaAl}_{2} \mathrm{Si}_{2} \mathrm{O}_{8}-$ $\mathrm{Na}_{2} \mathrm{CO}_{3}-\mathrm{H}_{2}$ O. Am. J. Sci. 273, 465487 (1973)

Wyllie, P.J.: Melting relationships in the system $\mathrm{CaO}-\mathrm{MgO}-\mathrm{CO}_{2}-\mathrm{H}_{2} \mathrm{O}$ with petrological applications. J. Petrol. 6, 101-123 (1965)

Wyllie, P.J.: Experimental data bearing on the petrogenetic links between kimberlites and carbonatites. Mineral. Soc. India, IMA Vol, 67--82 (1966)

Wyllie, P.J. : Phase equilibria in the system $\mathrm{CaO}-\mathrm{CO}_{2}-\mathrm{H}_{2} \mathrm{O}$ and related systems, with implications for crystal growth of calcite and apatite. J. Am. Ceram. Soc. 50, 43-46 (1967)

Wyllie, P.J., Biggar, G.M. : Fractional crystallization in the "Carbonatite systems" $\mathrm{CaO}-\mathrm{MgO}-$ $\mathrm{CO}_{2}-\mathrm{H}_{2} \mathrm{O}$ and $\mathrm{CaO}-\mathrm{CaF}_{2}-\mathrm{P}_{2} \mathrm{O}_{5}-\mathrm{CO}_{2}-\mathrm{H}_{2} \mathrm{O}$. Mineral Soc. India, IMA Vol., 92-105 (1966)

Wyllie, P.J., Cox, K.G., Biggar, G.M.: The habit of apatite in synthetic systems and igneous rocks. J. Petrol. 3, 238-243 (1962)

Wyllie, P.J., Haas, J.L., Jr.: The system $\mathrm{CaO}-\mathrm{SiO}_{2}-\mathrm{CO}_{2}-\mathrm{H}_{2} \mathrm{O}$. II the petrogenetic model. Geochim. Cosmochim. Acta 30, 525-543 (1966)

Wyllie, P.J., Tuttle, O.F.: The system $\mathrm{CaO}-\mathrm{CO}_{2}-\mathrm{H}_{2} \mathrm{O}$ and the origin of carbonatites. J. Petrol. 1, 1-46 (1960a)

Wyllie, P.J., Tuttle; O.F.: Experimental verification for the magmatic origin of carbonatites. Proc. 21 st Int. Geol. Congress, Copenhagen 13, 310-318 (1960b)

Received March 15, 1977 / Accepted May 21, 1977 